\title{
THE INTERACTION OF FIRE, VEGETATION AND LARGE MAMMALIAN HERBIVORES, ON ECOSYSTEM Processes in Yellowstone National Park
}

\author{
BENJAMIN TRACY $\bullet$ SAMUEL J. McNAUghtON \\ BIOLOGICAL RESEARCH LABORATORIES \\ SYRACUSE UNIVERSITY $\bullet$ SYRACUSE
}

\section{$\checkmark \quad$ INTRODUCTION}

There is substantial observational evidence suggesting positive interactions among fire, vegetation and large mammalian herbivores within Yellowstone National Park. The purpose of this research project is to quantify these potential interactions and explain their interactive effects on ecosystem processes (e.g. nutrient cycling). The basic study design utilizes burned areas from the 1988 fires with adjacent unburned areas to comparatively quantify ecosystem process information. Two paired study sites were chosen in three locations (Hellroaring Slope, Swan Lake Flat and Hayden Valley) representing winter, transitional and summer range for portions of the Northern elk herd. All study sites can be characterized as mesic sagebrush steppe dominated by the grasses Festüca idahoensis and Agropryron spp.

\section{- SUMMARY}

The primary objective of the 1991 field season was to collect 1) aboveground consumption and productivity data and 2) nitrogen and elemental soil data throughout the growing season. Additionally, since forests dominate such a large proportion of the Yellowstone landscape, one study site was added to access fire, large herbivore interactions within a forest/meadow mosaic. This site is located near
Grant Village and is currently being utilized by Jim Reardon and Jack Norland (NPS) for a fire related herbivory study. Only soil samples were collected at Grant Village this season. Other activities accomplished this field season included: a urea fertilization pilot study, initiation of a potential experimental burn at Hellroaring slope site, forage collection for nutrient analysis, collection of grasses for fungal endophyte analysis and collection of herbaceous root biomass. At present, preliminary analysis of 1991 aboveground consumption and productivity data has been accomplished, but the soil and forage samples are still being processed.

\section{$\checkmark \quad$ METHODS}

Aboveground productivity and consumption was measured with moveable exclosures $(1.5 \times 1.5 \mathrm{~m})$ at the Hellroaring and Hayden Valley sites from mid May until late August. Only peak standing crop data was collected at the Swan Lake Flat location because the study sites were relocated and grazing was very light. Four exclosures were randomly placed on each study site and moved at four week intervals throughout the growing season. Aboveground biomass was clipped inside and outside the exclosures within $25 \times 25 \mathrm{~cm}$ quadrats and sorted into live and standing dead components. Quadrat placement was randomly stratified because grazing generally was too uneven across the study sites to measure consumption 
efficiently. Actual (aPn) and grazed (gPn) net aboveground production was treated as the sum of positive growth increments inside and outside exclosures, respectively. Consumption $(\mathrm{H})$ was the difference between $\mathrm{aPn}$ and gPn. Significant consumption $(\mathrm{p}<.10)$ was measured using Student's t-test and ANOVA to compare biomass inside and outside exclosures. Nitrogen mineralization and soil elemental data was collected using an in situ method (see Raison et al. 1979). Soils were separated at 0-5 and 5-15 cm depths, except for Hellroaring Slope soils, which were separated at $5-10 \mathrm{~cm}$ depth due to high rock content. Soil sampling was randomly stratified within sagebrush interspaces when necessary. Soil samples were separately extracted each month for nitrogen and 19 different soil elements using $1 \mathrm{~N} \mathrm{KCl}$ and Mehlich solution (Mehlich 1984), respectively. Roots from each soil sample were saved. Extracts were then shipped back to Syracuse University for analysis at the end of the field season. For the urea pilot study, urea $(5.8 \mathrm{~g} / 3$ liter, four replicates/treatment) was applied to the Hayden Valley site in early June to measure $\mathrm{N}$ mineralization responses for the remainder of the growing season.

\section{- RESULTS}

Preliminary results from the 1991 field season indicate generally higher net aboveground production on burned areas compared to unburned areas (Table 1). This difference was significantly different at Hellroaring but not at the Hayden Valley site (ANOVA, $\mathrm{p}<.05$ ). Consumption was approximately $60 \%$ greater on the Hayden Valley burned sites compared to unburned sites throughout the growing season. This trend appeared to carry over into the late season as well, and it is notable that substantial consumption occurred in late August and September (not measured) as more elk and bison moved into the study area. Although consumption was higher on the Hayden Valley burned sites, observation of adjacent unburned areas indicate substantial consumption particularly occurring on south facing slopes. This suggests a possible topographic effect on grazing patterns that was not accounted for in the study design. . As mentioned earlier, grazing intensity was very uneven, especially at Hayden Valley, indicating that previously grazed patches may be regrazed during the growing season. Dung density was $50 \%$ higher (calculated from transect data) on the burned site compared to the unburned site at Hayden Valley, (t-test, $\mathrm{p}<.05)$.

No significant consumption was detected at the Hellroaring Slope unburned site while consumption on the burned site averaged $62 \mathrm{~g} \mathrm{~m}^{-2}$. This fact suggests that preferential grazing on the burned site in early May could have stimulated production beyond the that of the unburned site. Although consumption and production was not measured in 1990, standing dead biomass (May) was significantly higher $(\mathrm{t}$-test, $\mathrm{p}<.05)$ on the burned site $\left(30 \mathrm{~g} \mathrm{~m}^{-2}\right)$ compared to the unburned site $\left(14 \mathrm{~g} \mathrm{~m}^{-2}\right)$. This suggests that production in 1990 may have been higher on the burned site as well. Dung density showed the exact opposite pattern at Hellroaring Slope, being $50 \%$ greater on the unburned site compared to the burned site ( $t$-test, $\mathrm{p}<05$ ).

Soil N data from August 1990 indicate strong site and depth effects but little fire effects (ANOVA, $\mathrm{p}<.05$ ). Soil nitrogen data for 1991 has yet to be processed but initial data from 1990 could be related to the high production/consumption values at Hellroaring burned site (Table 1). The rather high mineralization value for the Hellroaring unburned site is inflated likely from animal urination over the soil sampling region and probably not reflective of the actual mineralization rate. The lower $\mathrm{N}$ mineralization values at the Hayden Valley site are likely a result of the soils high clay content (e.g Schimel et al. 1985). Preliminary soil elemental data also indicate strong site differences but moderate fire effects. However, both nitrogen and elemental soil data from 1990 is too preliminary for making meaningful inferences about aboveground production and consumption at this time but general patterns seem to be emerging.

\section{$\checkmark \quad$ FUTURE WORK}

Work to be completed for the remainder of the reporting period includes:

1) Soil nitrogen mineralization analysis

2) Forage nutrient analysis

3) Belowground biomass analysis 
Table 1. Preliminary production, consumption and nitrogen mineralization values at Hayden Valley and Hellroaring Slope. $\mathrm{aPn}=$ net aboveground productivity, $\mathrm{H}=$ consumption. Late season consumption at Hayden Valley was measured from late July to August. Values are $\mathrm{g} \mathrm{m}^{-2}$. Soil net $\mathrm{N}$ mineralization $(0-10 \mathrm{~cm})$ was measured for August 1990, mean values are ppm.

\begin{tabular}{lccccc|}
\hline & \multicolumn{2}{c}{ Hayden Valley } & \multicolumn{2}{c}{ Hellroaring Slp. } \\
& Burned & Unburned & Burned & Unburned \\
\hline aPn & 135 & 125 & 166 & 92 \\
$\mathrm{H}$ & 64 & 41 & 62 & $\mathrm{NS}$ \\
$\mathrm{H}$ (late season) & 56 & 37 & - & - \\
$\mathrm{N}$ mineralization & 0.60 & 1.11 & 3.94 & 5.40 \\
\hline
\end{tabular}

4) Belowground fertilization experiment accessing root responses to simulated urine/nutrient patches.

5) Controlled $\mathrm{N}$ mineralization experiment using bulk soils collected in Yellowstone

\section{$\checkmark \quad$ LITERATURE CITED}

Mehlich, A. 1984. Mehlich 3 soil test extrcat: A modification of Mehich 2 extract. Commun. Soil Sci. Plant Anal. 15: 1409-1416.
Raison,R.J., M.J. Connell and P.K. Khanna. 1987. Methodology for studying fluxes of soil mineral$\mathrm{N}$ in situ. Soil Biol. Biochem. 19:521-530.

J.S. Schimel, M.A. Stillwell, and R.G. Woodmansee. 1985. Biogeochemistry of C, N, and $P$ in a soil catena of the short grass steppe. Ecology 66:276-282. 